Research Paper

\title{
Application of the Principle of Piercing the Corporate Veil in Resolving Corporate Responsibility Cases in Indonesia
}

\section{Sandra Dewi ${ }^{1}$}

${ }^{1}$ Faculty of Law, Universitas Lancang Kuning, Indonesia.

Article History

Received:

18.08.2020

Revised:

23.09.2020

Accepted:

26.09.2020

*Corresponding Author:

Sandra Dewi

Email:

sandra.fh.unilak@gmail.com

This is an open access article, licensed under: $\mathrm{CC}-\mathrm{BY}-\mathrm{SA}$

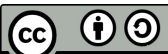

Abstract: This research aims to explain the application of the Principle of Piercing The Corporate Veil in resolving corporate responsibility cases in Indonesia. The method used in this research is normative legal research, using a statutory approach. The results of the research explain that based on Article 3 paragraph (1) of Law Number 40 of 2007 concerning Limited Liability Companies, it is stated that the shareholders of the company aren't personally responsible for the agreements made on behalf of the company and aren't responsible for the company's losses exceeding the shares they own. However, the doctrine in corporate law recognizes the existence of the Principle of Piercing The Corporate Veil which can break through the limited liability of the company's shareholders into unlimited liability up to their personal assets. Although the Principle of Piercing The Corporate Veil has been regulated in Law Number 40 of 2007 concerning Limited Liability Companies, there have been major cases in which the shareholders of the company were responsible up to their personal assets but only limited responsibility for the shares they owned. These major cases include the PT Lapindo Brantas case in 2006 and the PT Bank Century case in 2008.

Keyword: Corporate Veil, Law, Limited Liability Companies, Principle of Piercing. 


\section{Introduction}

Modern society is a business society. All humans, both in cities and in villages, have a relationship with business. There is no person living in modern times who isn't touched by business activities, including the business activities of large companies. Business development encourages the development of economic law, especially those related to globalization issues. The role of law in economic development has been global. Law doesn't only play a conventional role, but also serves and accommodates large changes on a broader scale. In national and international changes facing major changes due to globalization, the law isn't sufficient only to be anticipatory, but must be able to design the future of the nation in economic development. Thus, the law isn't only intended to protect national interests from the process of economic globalization, but must also be endeavored to enable Indonesia to play a role in controlling, managing, and simultaneously taking advantage of globalization through various formulations.

Although it is recognized that the role of law will always lag behind the pace of development and progress in the economic field, it doesn't mean that there is no preparation at all in the legal sector, many laws and regulations have been issued regulating new things following global trends, including ratification of Law Number 40 of 2007 concerning Limited Liability Companies.

Law Number 40 of 2007 concerning Limited Liability Companies can be viewed as an instrument of economic activity that contains various advantages, including regarding the limited liability system of Limited Liability Companies which will facilitate business access to investment with all the consequences of risk of loss or profit opportunities attached to it. Limited Liability Company is an association to run a business that has capital consisting of shares, whose owners have as much share as the shares they own. Because the capital consists of tradable shares, changes in the ownership of the Limited Liability Company can be made without the need to dissolve the Limited Liability Company.

The assets of the Limited Liability Company are separate from the personal assets of the owner so that the Limited Liability Company has its own assets. Limited Liability Company is a legal entity established based on an agreement to carry out business activities with authorized capital which is entirely divided into shares and meets the requirements stipulated in the law and its implementing regulations. Shares are the most important capital of a Limited Liability Company at the time the Limited Liability Company is established, as regulated in Article 31 paragraph (1) of Law Number 40 of 2007 concerning Limited Liability Companies that the capital of a Limited Liability Company consists of the entire nominal value of the shares.

Each person can own more than one share which is proof of ownership of a Limited Liability Company. Part of the capital or shares can be known who owns it and how much is it through the register of shareholders' books. Article 50 paragraph (1) of Law Number 40 of 2007 concerning Limited Liability Companies states that as proof of ownership, the names of shareholders are recorded in the Register of Shareholders of Limited Liability Companies. Limited Liability Companies can carry out their activities in accordance with the aims and objectives of their establishment by collecting the capital. If the Limited Liability Company gets a profit, then the shareholders are entitled to enjoy that benefit, which is known as dividend [1].

In a Limited Liability Company, apart from separate company assets and capital owner assets, there is also a separation between the company owner and the company management. Management of the company can be submitted to personnel who are experts in their fields. The limited liability company organizational structure consists of shareholders, directors, and commissioners. For this reason, a clear legal framework is needed so that directors and commissioners can work productively and efficiently and there are clear legal rules for Limited Liability Companies in carrying out their activities.

As an artificial person, a Limited Liability Company cannot act alone. The Limited Liability Company does not have the will to carry it out in accordance with the aims and objectives of the Limited Liability Company establishment. Therefore, in acting and being responsible, Limited Liability Companies are represented by the board of directors and commissioners. Rudhi Prasetya stated that when talking about accountability, it can be seen in terms of external relations and in terms of internal relations. External responsibility is responsibility as an impact in relations with outside parties, while internal responsibility is the impact of the relationship between the management of the Limited Liability Company as an organ of other Limited Liability Company organs [2]. 
The main goal of a company is to get the maximum profit. This is the responsibility of the management of the company to the shareholders as owners of the company. This is the philosophical basis of establishing a company. However, the company's operational activities in order to maximize profits often harm the community, especially those who live near the company's location. This problem is the basis for the concept of corporate social responsibility [3].

The objectives of a Limited Liability Company can be achieved if the organs of a Limited Liability Company in managing the company implement the Principles of Good Corporate Governance. The ability to compete and the success achieved by the Limited Liability Company is the contribution of various parties in the form of capital, expertise, services, products, and others. On this basis, the Limited Liability Company should recognize well the contributions of each stakeholder, including investors, employees, creditors, suppliers, customers, and regulators, all of whom are referred to as stakeholders [4]. The purpose of establishing a Limited Liability Company in the long term is the creation of prosperity and prosperity not only for shareholders, but also for all stakeholders [5].

Based on Article 3 paragraph (1) of Law Number 40 of 2007 concerning Limited Liability Companies, it is stated that the shareholders of the company are not personally responsible for the engagement made on behalf of the company and are not responsible for the company's losses in excess of the shares they own. Limited liability of the shareholders of a Limited Liability Company is a curtain that separates the responsibilities of the shareholders from the responsibilities of the management in carrying out the business activities of the Limited Liability Company. However, the doctrine in corporate law recognizes the existence of the Principle of Piercing the Corporate Veil which can break through the limited liability of the company's shareholders into unlimited liability up to their personal assets.

From the background of the problems described above, the problem discussed in this study is how to apply the Principle of Piercing the Corporate Veil in solving cases of corporate responsibility in Indonesia?

\section{Research Methodology}

Legal research is a scientific activity based on methods, systematics, and certain thoughts that aim to study one or more specific legal phenomena by analyzing them [6]. The method used in this research is normative legal research, using a statutory approach. Normative legal research is a process to find legal rules, legal principles, and legal doctrines in order to answer legal issues faced [7]. Sources of data used in this study are secondary data, namely data obtained from statutory regulations, scientific journals, and legal literature. The data collection technique used in this research is literature study. The data analysis technique used in this research is qualitative analysis.

\section{Discussion}

The principle of Piercing the Corporate Veil has existed in Indonesia since the enactment of Law Number 1 of 1995 concerning Limited Liability Companies which was present to replace several regulations regarding Limited Liability Companies in the Indonesian Commercial Code. Law Number 1 of 1995 concerning Limited Liability Companies was later repealed and replaced by Law Number 40 of 2007 concerning Limited Liability Companies which introduced several new legal principles regarding the organs of Limited Liability Companies, but retained the Principle of Piercing the Corporate Veil which gave an exception to the principle of liability. Limited liability that applies to the shareholders of the Limited Liability Company.

The Principle of Piercing the Corporate Veil is accommodated in the Limited Liability Company Law as the influence of foreign laws imported from countries that adhere to the Anglo Saxon legal system. The principle of Piercing the Corporate Veil teaches that although a legal entity is legally responsible only to the extent of the assets of the legal entity, in certain cases the limit of that responsibility can be breached [8]. During its development, the Principle of Piercing the Corporate Veil can even be applied to the responsibilities of directors and commissioners in managing the company.

Based on Article 3 paragraph (1) of Law Number 40 of 2007 concerning Limited Liability Companies, it is stated that the shareholders of the company are not personally responsible for the engagement made on behalf of the company and are not responsible for the company's losses in excess of the shares they own. 
In Law Number 40 of 2007 concerning Limited Liability Companies the term piercing the Corporate Veil Principle doesn't sound, but the form of the Principle of Piercing the Corporate Veil is contained in Article 3 paragraph (2) of Law Number 40 of 2007 concerning Limited Liability Companies, which confirms that the limited liability of the company shareholders doesn't apply if:

- The requirements of the company as a legal entity aren't fulfilled or not.

- Shareholders of the company, either directly or indirectly, in bad faith use the company for personal gain.

- Shareholders of the company are involved in illegal acts committed by the company.

- Shareholders of the company, either directly or indirectly, have illegally used the company's assets which resulted in insufficient company assets to pay off the company's debts.

Limited liability as regulated in Article 3 paragraph (1) of Law Number 40 of 2007 concerning Limited Liability Companies isn't absolute. In the sense that there is an exemption from limited liability in Article 3 paragraph (2) of Law Number 40 of 2007 concerning Limited Liability Companies known as the Principle of Piercing The Corporate Veil. If there is a situation as regulated in Article 3 paragraph (2) of Law Number 40 of 2007 concerning Limited Liability Companies above, then the responsibility of the company's shareholders, which was initially limited to the amount of capital (shares) they own, can be held accountable unlimited, even to his personal property. The principle of Piercing the Corporate Veil has been used in Indonesia as jurisprudence [9].

Courts in Indonesia have applied the Piercing the Corporate Veil Principle in deciding legal issues regarding the limited liability of the shareholders of a Limited Liability Company. Decision of the Supreme Court of the Republic of Indonesia Number 21K / Sip / 1973 dated 5 November 1973 in the case of PT Perusahaan Pelayaran Samudra 'Gesuri Lloyd' against O. Sibarani (PT Toko Tujuh Belas) stated that apart from being a shareholder of the company, O. Sibarani also sits as a member The directors of the company and therefore were deemed to have violated the conditions for the establishment of a Limited Liability Company because they used the Limited Liability Company for their personal interests, so O. Sibarani was punished to compensate the company for losses up to his personal assets.

Not only that, in the case of the transfer of shares of PT Indotruba Tengah, Darsono, Siswanto, and Joso Prayitno who are shareholders of PT Mulia Argo Persada as well as the company management, transferred rights over shares of 6,200 shares of PT Indotruba Tengah to PT Mulia Argo Persada. The Kartika Ekapaksi Foundation as the owner of PT Indotruba Tengah shares then filed a lawsuit so that Darsono, Siswanto, and Joso Prayitno return the shares to the Kartika Ekapaksi Foundation. The Central Jakarta District Court ruled that the transfer of rights to shares belonging to the Kartika Ekapaksi Foundation in PT Indotruba Tengah to PT Mulia Argo Persada was declared null and void, but this decision didn't apply the Principle of Piercing the Corporate Veil. However, according to the judges at the Jakarta High Court and the Supreme Court of the Republic of Indonesia, the decision was made even more aggravated by applying the Principle of Piercing the Corporate Veil by ordering Darsono, Siswanto, and Joso Prayitno to compensate for the material losses of the Kartika Ekapaksi Foundation up to their personal assets.

Finally, in the decision of the Karawang District Court Number 61 / Pdt / G / 2008 / PN-KRW which is strengthened by the Bandung High Court decision Number 496 / Pdt / 2010 / PT-BDG and the decision of the Supreme Court of the Republic of Indonesia Number 1811K / PDT / 2011 on the case Yoshiaki Takamichi against PT Multiprima Jayaputra Abadi and the decision of the South Jakarta District Court Number 313 / Pdt.G / 2011 / PN-Jkt.Sel in the case of PT Bank CIMB Niaga against PT Adi Partner Perkasa was decided by the court by applying the Principle of Piercing The Corporate Veil.

Even though the Principle of Piercing The Corporate Veil has been adopted in Article 3 paragraph (2) of Law Number 40 of 2007 concerning Limited Liability Companies, it turns out that there have been major cases where the company's shareholders were responsible up to their personal assets but were decided only to the extent of their responsibility the shares it owns. These major cases include the PT Lapindo Brantas case in 2006 and the PT Bank Century case in 2008.

In a study entitled "Legal Protection for Customers against Losses Due to Transfer of Assets Based on the Principle of Piercing The Corporate Veil in Relation to the Responsibility of Commissioners", Gios Adhyaksa explained that for a Limited Liability Company in the banking sector, Law Number 
40 of 2007 concerning Limited Liability Companies and Law Number 7 of 1992 concerning Banking and Law Number 10 of 1998 concerning Amendments to Law Number 7 of 1992 concerning Banking can be used as a legal basis in assessing the application of the Piercing The Corporate Veil Principle in the PT Bank Century case.

After examining the PT Bank Century case, it was discovered that there were several legal issues that had resulted in the Limited Liability Company and its stakeholders experiencing losses, namely that the shareholders, directors and commissioners of PT Bank Century both abused their authority and used the Limited Liability Company for personal gain. PT Bank Century was proven to have committed illegal acts since its inception. There are efforts that can be made in implementing the responsibilities of a Limited Liability Company to stakeholders, namely by applying the Principle of Piercing the Corporate Veil. The principle of Piercing The Corporate Veil is one of the efforts made by the government to provide a sense of justice for stakeholders by asking for full responsibility from shareholders, directors and commissioners of PT Bank Century up to their personal assets by disregarding the limited liability stipulated in the Law Number 40 of 2007 concerning Limited Liability Companies [10].

The application of the principles of good corporate governance is necessary to build public and international trust as an absolute prerequisite for the banking sector to develop properly. Therefore, the Bank for International Sattlement as an institution that studies the prudential principles that banks must adhere to has issued guidelines for the implementation of good corporate governance for the banking sector internationally [11]. As an intermediary and trust institution, in carrying out its business activities, banks must adhere to the principle of transparency, have performance measures for all levels of the bank based on measures consistent with corporate values, business objectives and bank strategies as a reflection of bank accountability, adhere to prudential banking, practices and guarantees the implementation of applicable regulations as a form of bank responsibility, objective, and free from pressure from any party in making decisions, and always takes into account the interests of all stakeholders based on the principles of equality and fairness [12].

In the principle of openness, a bank must be:

- First, disclose information in a timely, adequate, clear, accurate, comparable and easily accessible manner to stakeholders according to their rights.

- Second, the information that must be disclosed includes, but isn't limited to matters relating to the company's vision, mission, business objectives and strategy, financial condition, composition and compensation of the management, controlling shareholders, cross shareholding, executive officers, risk management, systems internal supervision and control, compliance status, system and application of the Principles of Good Corporate Governance, as well as important events that may affect bank conditions.

- Third, the principle of transparency adopted by banks doesn't reduce the obligation to comply with bank secrecy regulations in accordance with the prevailing laws and regulations, position secrets and personal rights. Finally, bank policies must be written and communicated to interested parties and those entitled to obtain information about the policy.

In the principle of accountability, a bank must be:

- First, define clear responsibilities for each organizational organ that is aligned with the company's vision, mission, business objectives and strategy.

- Second, banks must ensure that all of the bank's organizational organs have the competence in accordance with their responsibilities and understand their role in the application of the Principles of Good Corporate Governance.

- Third, banks must ensure there is a check and balance system in bank management.

- Finally, a bank must have a performance measure of all levels of the bank based on agreed measures consistent with company value, business objectives and bank strategy, and have a rewards and punishment system.

In the principle of responsibility, a bank must be:

- First, to maintain the continuity of its business, a bank must adhere to the principle of prudence and ensure the implementation of applicable regulations. 
- Second, banks must act as good corporate citizens, including caring for the environment and carrying out social responsibility.

In the principle of independence, a bank must be:

- First, the bank must avoid unnatural domination by certain stakeholders and be free from conflicts of interest.

- Second, in making decisions, banks must be objective and free from any pressure from any party.

In the principle of fairness, a bank must be:

- First, the bank must always pay attention to the interests of all stakeholders based on the principles of equality and fairness.

- Second, banks must provide opportunities for all stakeholders to provide input and convey opinions for the bank's interests and have access to information in accordance with the principle of openness.

Unlike conventional banks, the principles of Good Corporate Governance in Islamic banks are strictly regulated in Article 34 paragraph (1) of Law Number 21 of 2008 concerning Islamic Banking, which confirms that Islamic banks are required to implement good governance which includes the principles of transparency, accountability, responsibility, professionalism and fairness in carrying out business activities [13].

As the owner of a Limited Liability Company, it is possible for the shareholders of the company to directly or indirectly in bad faith take advantage of the company for their personal interests, be involved in illegal acts committed by the company, and directly or indirectly use the company's assets against the law so that the company's assets become not enough to pay off the company's debt. Therefore, the application of the Principle of Piercing the Corporate Veil can support the realization of the Principles of Good Corporate Governance in order to prevent abuse of power by company shareholders.

\section{Conclusion}

Based on Article 3 paragraph (1) of Law Number 40 of 2007 concerning Limited Liability Companies, it is stated that the shareholders of the company aren't personally responsible for the engagement made on behalf of the company and aren't responsible for the company's losses in excess of the shares they own. However, the doctrine in company law recognizes the existence of the Principle of Piercing the Corporate Veil which can break through the limited liability of the company's shareholders into unlimited liability up to their personal assets.

The Principle of Piercing The Corporate Veil stipulates that the limited liability of the company's shareholders doesn't apply if the requirements of the company as a legal entity haven't been or aren't fulfilled, the company's shareholders directly or indirectly in bad faith use the company for their personal interests, the company's shareholders are involved in actions against the law committed by the company, as well as the company's shareholders directly or indirectly using the company's assets against the law so that the company's assets become insufficient to pay off the company's debt. Although the Principle of Piercing the Corporate Veil has been regulated in Law Number 40 of 2007 concerning Limited Liability Companies, there have been major cases where the company's shareholders are responsible up to their personal assets but only limited responsibility for the shares they own. These major cases include the PT Lapindo Brantas case in 2006 and the PT Bank Century case in 2008.

\section{References}

[1] Muladi, Company Law; Business Entities in Indonesia. Bogor: Ghalia Indonesia, 2010.

[2] R. Prasetya, Independent Position of Limited Liability Company. Bandung: Citra Adytia Bakti, 1996.

[3] Hasnati and A. S. Utama, "Implementation of Corporate Social Responsibility (CSR) by Forestry and Plantation Companies in Pelalawan Regency Riau Province, Indonesia," Journal of Law and Political Sciences, vol. 25, no. 4, 2020. 
[4] Hasnati, Independent Commissioner and Audit Committee; Company Organs Role to Achieve Good Corporate Governance in Indonesia. Yogyakarta: Absolute Media, 2014.

[5] L. J. Susilo, Good Corporate Governance at the Bank. Bandung: Hikayat Dunia, 2007.

[6] S. Seokanto, Introduction to Legal Research. Jakarta: UI Press, 2007.

[7] P. M. Marzuki, Legal Research. Jakarta: Kencana, 2011.

[8] M. Fuady, Company Law in Business Law Paradigm. Bandung: Citra Aditya Bakti, 2002.

[9] C. Ais, "The Influence of the Principle of Piercing the Corporate Veil in Indonesian Company Law," Hukum Bisnis Journal, vol. 22, no. 6, 2003.

[10] G. Adhyaksa, "Legal Protection for Customers against Losses Due to Transfer of Assets Based on the Principle of Piercing the Corporate Veil in Relation to the Accountability of Commissioners," Unifikasi Journal, vol. 2, no. 1, 2015.

[11] A. S. Utama, "Independency of Supervision of State-Owned Enterprises of Banks in the National Legal System in Indonesia," Soumatera Law Review Journal, vol. 1, no. 1, pp. 1-21, 2018.

[12] D. S. Hasnati and A. S. Utama, "Comparison of the Principles of Good Corporate Governance," in Conventional Banks and Islamic Banks in the Legal System in Indonesia, Mizan Journal, vol. 3, no. 2, pp. 197-207, 2019.

[13] A. S. Utama, "Good Corporate Governance Principles in Indonesia Syariah Banking," International Journal of Law and Public Policy, vol. 2, no. 1, pp. 11-16, 2020. 